\title{
Brot für die Hauptstadt. Niederösterreich und die Nahrungsversorgung Wiens
}

\begin{abstract}
Der Beitrag legt seinen Fokus auf die Nahrungsmittelversorgung Wiens in der ersten Hälfte des I9. Jahrhunderts. Die Periode vor der Einführung von industriellen Transportmitteln wurde von der Forschung bisher wenig thematisiert. Die Geschichte jener Zweige der Nahrungsmittelversorgung, die sich in Niederösterreich befanden, kann nur im Kontext grenzüberschreitender Netzwerke und Warenströme verstanden werden. Der Text analysiert daher die Warenkette bzw. food chain Getreide. Bereits vor I850 waren der Brotkonsum in Wien und die Verarbeitung von Weizen im südlichen Wiener Umland in internationale Güterketten eingebunden. Sie waren von Rohstofflieferungen aus relativ weit entfernten Regionen und Ökosystemen in der Peripherie der Monarchie abhängig bzw. profitierten sie von diesen.
\end{abstract}

Bread for the Metropolis. Lower Austria and Vienna's Food Supply. This chapter analyses the food supply to the city of Vienna during the first half of the $19^{\text {th }}$ century, with a focus on two key points: first, it will be argued that the period before the introduction of industrial means of transportation has been largely neglected by historians when it comes to the history of Vienna's food supply and the Lower Austrian industries involved. Second, the chapter shows that this story can only be told as a history of growing cross-border interconnections and commodity flows. The study thus analyses the food or commodity chain of grain. It concludes that well before 1850 , bread consumption in Vienna and flour production in the city's southern environs were essentially integrated into international commodity chains, profiting from streams of raw materials from relatively distant regions and ecosystems on the empire's periphery.

Keywords: wheatification, grain quality, milling, industrialisation

doi.org/10.52035/noil.2021.19jh02.17

Veröffentlicht nach externer Begutachtung (doppelblind) / published after external peer review (double blind) 